\title{
Mangrove diversity and community structure of Mimika District, Papua, Indonesia
}

\author{
GESANG SETYADI $^{1, \bullet}$, RUDHI PRIBADI ${ }^{2}$, DIAH PERMATA WIJAYANTI ${ }^{2}$, DENNY NUGROHO SUGIANTO ${ }^{3}$ \\ ${ }^{1}$ Doctorate Program in Marine Science, Faculty of Fisheries and Marine Sciences, Universitas Diponegoro. Jl. Prof. Soedarto, Tembalang, Semarang \\ 50725, Central Java, Indonesia. Tel./fax.: +62-298-7474698. "email: gesang.setyadi@ gmail.com \\ ${ }^{2}$ Department of Marine Science, Faculty of Fisheries and Marine Sciences, Universitas Diponegoro. Jl. Prof. Soedarto, Tembalang, Semarang 50725, \\ Central Java, Indonesia \\ ${ }^{3}$ Department of Oceanography, Faculty of Fisheries and Marine Sciences, Universitas Diponegoro. Jl. Prof. Soedarto, Tembalang, Semarang 50725, \\ Central Java, Indonesia
}

Manuscript received: 7 February 2021. Revision accepted: 30 July 2021.

\begin{abstract}
Setyadi G, Pribadi R, Wijayanti DP, Sugianto DN. 2021. Mangrove diversity and community structure of Mimika District, Papua, Indonesia. Biodiversitas 22: 3562-3571. Despite being one the largest mangrove forest in the world, there are few studies on mangrove diversity and community structure in Mimika, Papua Province. The study collected data from 4 estuaries of Mimika Region, i.e. Kamora, Tipuka, Ajkwa and Minajerwi. Mangrove species, tree diameter at breast height and canopy height data were collected in $10 \mathrm{~m} \times 10 \mathrm{~m}$ plot with three replicates for distance, specifically 0,250 , and 500m perpendicular to the riverbank. This study found 66 mangroves species consisting of 20 major, 10 minor, and 36 associate mangrove species. Their density ranged from $577-1,345$ trees ha $^{-1}$ with diversity Shannon-Weiner diversity indices (H') ranging from 0.62-1.19 and Evenness Index (J') ranging from 0.09-0.18. The canopy height of the mangrove trees was ranged from $9-42.5 \mathrm{~m}$. The highest density species was Rhizophora apiculata (333 ha ${ }^{-1}$ ) followed by Avicennia marina, Bruguiera gymnorrhiza, and Camptostemon schultzii, while B. parviflora, S. alba, and X. granatum were the least dominant. Regarding basal area, R. apiculata and B. gymnorrhiza were the highest with medians of $7,853 \mathrm{~cm}^{2} \mathrm{ha}^{-1}$ and 5,201 $\mathrm{cm}^{2} \mathrm{ha}^{-1}$ respectively. In the low tidal zone area, mangrove was dominated by A. marina, Sonneratia alba and $R$. mucronata. Medium low to medium high tidal zones were dominated by B. gymnorrhiza, R. apiculata, and B. parviflora. The high tidal zone was more dominated by Nypa fruticans.
\end{abstract}

Keywords: diversity, density, mangrove, Mimika, Papua, stratification, species richness

\section{INTRODUCTION}

The mangrove forests of Indonesia are among the most species-rich and extensive in the world, representing around $20-23.5 \%$ of the world's total mangrove area (Giri et al. 2011; Ilman et al. 2011). There are various assessments of the total area of Indonesia's mangrove forests ranging from 2.4-7.8 million ha (Kusmana 2015; Rizal et al. 2018). The majority of Indonesia's mangrove forests are found in Papua (58\%), Kalimantan (16\%) and Sumatra $(19 \%)$ with the rest found in Sulawesi, Java, and Maluku (Hanum et al. 2014).

According to Hogarth (2015), true mangroves comprise 70 species belonging to 20 families in which 47 species represent the major component (true, strict, or exclusive mangrove species). In Indonesia, Rizal et al. (2018) have recorded 89 species, 35 being trees. Hanum et al. (2014) report finding 202 mangrove species in Indonesia consisting of 43 true mangrove species and the remaining mangrove associates. About 166 species were found in Java, 157 in Sumatra, 150 in Kalimantan, 142 in Papua, 135 in Sulawesi, 133 in Maluku, and 120 species in the Lesser Sunda Islands.

Most mangrove diversity and distribution studies in New Guinea have been carried out in Papua New Guinea (Shearman 2010). It is estimated that Papua New Guinea contains 592,900 ha of mangroves, which are distributed along the coastal provinces (Shearman et al. 2009). In Papua, Indonesia, there is an estimated 1.4-1.6 million ha of mangroves, making the country home to one of the largest mangrove areas in the world (Hanum et al. 2014; Rizal et al. 2018). Based on data from the Ditjen PDASHL, Ministry of Environment and Forestry, Republic of Indonesia (2019), there are 1,497,724 hectares of total mangrove area in the provinces of West Papua and Papua. Mimika District is located in the southern part of Papua. This district has a complete landscape from mangroves in coastal areas, peat swamp forests, lowland forests, and mountainous areas through to icy alpine zones. The estimated mangrove area of Mimika is 186,291 ha (Aslan et al. 2018). Several studies have been carried out in the area on topics such as the distribution of carbon stock (Taberima et al. 2017), the history of sediment and trace element deposition in the Ajkwa River and the Holocene palynology of Mimika (Brunskill et al. 2004; Ellison 2005), and the mapping of the distribution, biomass, and mangrove canopy of Mimika using remote sensing (Aslan et al. 2018). However, research on mangrove forests in Papua, particularly along the southern coast and in Mimika is limited. With its vast mangrove area, the province of Papua in Indonesia is probably the most pristine and diverse mangrove forest in the world, with just 29-32 
obligate taxa of mangrove flora being recorded in Papua New Guinea (Johnstone and Frodin 1982). Given the above, this study aims to determine the species richness and density of mangrove vegetation in four estuaries in Mimika District, describe vegetation composition, structure, and Species Importance Value, and determine mangrove stratification based on tidal zones in the area. The results of this study will provide a better understanding of the mangrove ecosystem in Mimika, most of which is classified as a Protected Forest under the Ministry of Forestry, Republic of Indonesia, Decree SK.782/MenhutII/2012.

\section{MATERIALS AND METHODS}

\section{Study area}

The mangrove forest in four estuaries in Mimika District, Papua, Indonesia, i.e., Kamora, Tipuka, Ajkwa, and Minajerwi Estuaries, were selected for study. The forest covers an area of $600 \mathrm{~km}^{-1}$. The geographic positions of the sampling locations are presented in Table 1 and Figure 1. The four estuaries drain large catchments that extend to the $3000-4,500 \mathrm{~m}$ mountain crests. The catchments receive extremely high volumes of annual rainfall (4-13 $\mathrm{m} \mathrm{yr}^{-1}$; Setyadi et al. 2009). The mangrove forest community extends about $20 \mathrm{~km}$ inland from the coastline. The estuaries are considered to contain high hydraulic energy due to rainfall magnitudes and the 3.3-3.6 $\mathrm{m}$ tidal ranges (Aslan et al. 2018).

\section{Procedures}

Nine locations were surveyed: three in the Kamora Estuary, two in the Tipuka Estuary, three in the Ajkwa
Estuary and one in the Minajerwi Estuary (Table 1). Sampling was conducted in March 2019. Analysis of the structure and composition of mangrove vegetation was carried out using the line transect plot method (MuellerDumbois \& Ellenberg 1974). At each location, mangrove tree data were collected at 0,250 , and $500 \mathrm{~m}$ perpendicular to the riverbank (Figure 2). At each of sublocations, mangrove trees were surveyed in triplicates of $10 \mathrm{~m} \times 10 \mathrm{~m}$ quadrants (Pribadi 1998; Ganivet \& Bloomberg 2019). Since mangrove trees have a unique shape and growth form which sometimes creates difficulties in deciding where to measure the diameter, a recommendation by Cintron \& Novelli (1984) will be applied, where each branch (dbh $\geq$ $10 \mathrm{~cm}$ ) will be measured at $1.3 \mathrm{~m}$ above the ground level. The species found in each plot was identified and classified taxonomically using classification from Hogarth (2015). Three height was measured by using clinometer and laser distance meter which are considered as very accurate to measure tree height (William et al. 1994).

Table 1. Coordinates mangrove sampling locations in Mimika Region, Papua, Indonesia

\begin{tabular}{llll}
\hline Station & Location & Latitude $(\mathbf{S})$ & Longitude (E) \\
\hline TIP-1 & Tipuka Estuary & $4^{\circ} 45^{\prime} 32.5^{\prime \prime}$ & $136^{\circ} 51^{\prime} 48.9^{\prime \prime}$ \\
TIP-2 & Tipuka Estuary & $4^{\circ} 47^{\prime} 10.9^{\prime \prime}$ & $136^{\circ} 51^{\prime} 16.9^{\prime \prime}$ \\
KAM-1 & Kamora Estuary & $4^{\circ} 47^{\prime} 51.7^{\prime \prime}$ & $136^{\circ} 41^{\prime} 58.1^{\prime \prime}$ \\
KAM-2 & Kamora Estuary & $4^{\circ} 48^{\prime} 00.6^{\prime \prime}$ & $130^{\circ} 41^{\prime} 06.2^{\prime \prime}$ \\
KAM-3 & Kamora Estuary & $4^{\circ} 49^{\prime} 09.2^{\prime \prime}$ & $136^{\circ} 41^{\prime} 01.2^{\prime \prime}$ \\
AJK-1 & Ajkwa Estuary & $4^{\circ} 51^{\prime} 15.8^{\prime \prime}$ & $136^{\circ} 533^{\prime} 31.2^{\prime \prime}$ \\
AJK-2 & Ajkwa Estuary & $4^{\circ} 53^{\prime} 53.8^{\prime \prime}$ & $136^{\circ} 52^{\prime} 08.2^{\prime \prime}$ \\
AJK-3 & Ajkwa Estuary & $4^{\circ} 55^{\prime} 12.1^{\prime \prime}$ & $136^{\circ} 50^{\prime} 07.3^{\prime \prime}$ \\
MIN-1 & Minajerwi Estuary & $4^{\circ} 55^{\prime} 17.8^{\prime \prime}$ & $137^{\circ} 00^{\prime} 54.6^{\prime \prime}$ \\
\hline
\end{tabular}

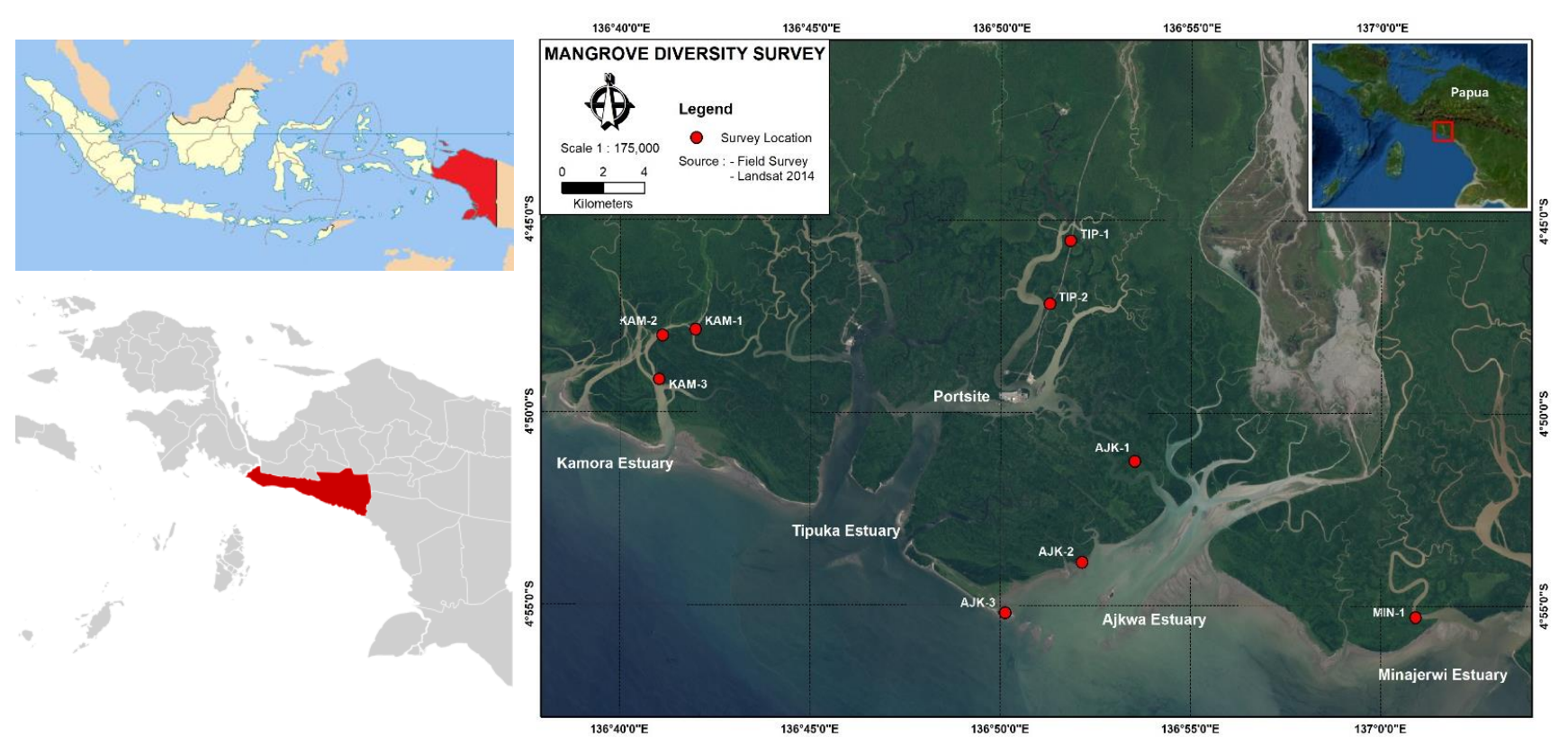

Figure 1. Study area in Mimika District, Papua, Indonesia, and sampling locations of the four estuaries 


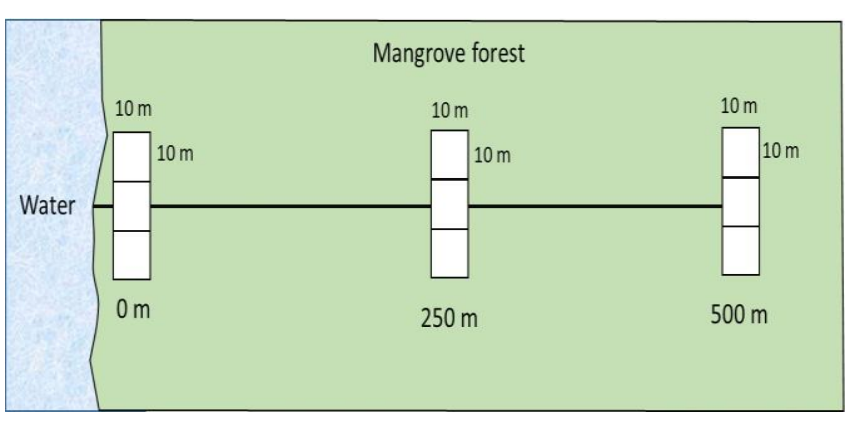

Figure 2. Line transect plot at each sampling location

Additional qualitative vegetation data was carried out in June 2020 to determine mangrove zonation from low tidal zone area down to coastline along the Tipuka and Ajkwa Estuaries. Every approximately $2 \mathrm{~km}$, rapid assessment on the most dominant species was recorded at $20 \times 20$ plots (Ganivet \& Bloomberg 2019). Photos of the flora, tree height, and estimation of canopy cover were also recorded.

\section{Data analysis}

The vegetation data was analyzed using the method provided by Lavaisha and Mangora (2016), which includes relative frequency $(\mathrm{RF})$, relative density $(\mathrm{RD})$, and relative dominance (RDo). The Species Importance Values (SIV) of each species were determined by adding together the respective relative frequency, relative density, and relative dominance. The relative dominance of a species is measured according to how often it occurs, its numbers, and the area it occupies in a community. Species diversity was estimated using Shannon-Wiener Index (H') and Evenness (J') (Shannon \& Wienner 1993) as follows.

$$
\begin{aligned}
& \text { R }
\end{aligned}
$$

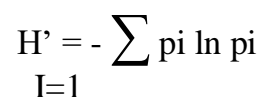

Where: H' = Shannon-Wiener Index of Diversity, pi= $\mathrm{ni} / \mathrm{N}$, where $\mathrm{ni}=$ total number of individuals of species $\mathrm{i}$ in the quadrat/sample and $\mathrm{N}=$ total number of individuals of all the species in the quadrat/sample. According to Odum and Barret (2004) the Shannon-Winner diversity index is classified into three levels: low $(\mathrm{H}<2)$, moderate $(2<\mathrm{H}<$ $4)$, and high $(\mathrm{H}>4)$.

The evenness (J'), a measure of the equitability of species abundances, was derived using $H^{\prime}$ where $S$ is the total number of species. The evenness value of $0.6-1$ is classified as high, the value of $0.4<\mathrm{J}^{\prime}<0.6$ is moderate and for values $0-0.4$ is low (Krebb 1989). Below is the quotation (Pielou 1975):

$$
\mathrm{J}^{\prime}=\frac{\mathrm{H}^{\prime}}{\ln \mathrm{S}}
$$

The classification of mangrove zones was determined by the elevation of and duration of inundation for each plot. Elevation data was obtained using Light Detection and
Ranging (LIDAR), while the duration of inundation was calculated using the 2019 Tidal Table provided by PUSHIDROSAL (Indonesian Navy Hydrographic and Oceanographic Center). Four classifications were established (Tusinski and Verhagen 2014):low tidal zone $(<0.5 \mathrm{~m})$; medium-low tidal zone $(0.5-1.5 \mathrm{~m})$; medium-high tidal zone $(1.5-2 \mathrm{~m})$; and high tidal zone $(>2 \mathrm{~m})$. The density data of each plot was used to determine the mangrove vegetation included in each classification.

\section{RESULTS AND DISCUSSION}

\section{Species richness and densities}

Fifteen mangrove species were observed in the plot area. Additional data collected from the adjacent transect plot found a total of 66 species comprising 20 species of major mangrove components, 10 species of minor components, and 36 species of mangrove associates (Table 2). Classification was based on Hogarth (2015).

The density, Shannon-Wiener diversity index (H'), and evenness index (J') of the mangrove trees surveyed are shown in Table 3. Based on the data, the density of the mangrove trees in the study area ranged from 577-1,345 trees ha ${ }^{-1}$ (average 773 trees ha $^{-1}$ ). Although the tree density of station AJK-3 in the Ajkwa Estuary was 2.3 times higher than that of Station KAM-2 in the Kamora Estuary, this was not a significant difference, as indicated by the overlapping standard deviations. The high diversity found in the Ajkwa Estuary is due to the mangrove succession process prevalent in the area caused by wave action and sedimentation. Due to its position in the seaward margin, the vegetation was denser but smaller in diameter.

The table above reveals that the Shannon-Wiener diversity index ( $\left.\mathrm{H}^{\prime}\right)$ for the mangrove trees in the study area ranged from 0.62-1.19, which is categorized as low. The highest diversity index was recorded for AJK-3 in the Ajkwa Estuary and the lowest for MIN-1 in the Minajerwi Estuary. AJK-3 is located in a low tidal zone where natural succession and new colonization occur particularly along the edge of the mangroves $(0 \mathrm{~m})$. Here, pioneer species such as A. marina and $S$. alba are dominant. However, other species commonly found in the medium tidal zone were also found in the low tidal zone at a higher elevation of $500 \mathrm{~m}$, such as $R$. apiculata, B. parviflora, B. gymnorrhiza, and $L$. littorea. The wide range in elevation at one location might be the cause of higher diversity. As the key of mangrove adaptations is the ability to survive in the waterlogged and anoxic soil and ability to tolerate saltwater (Hogarth 2015), differences in elevations will cause different frequencies of inundation and salinity, which may control the mangrove diversity. Thus, the distribution of mangrove species will be varied based on species tolerance to the inundation and salinity from aerial root architecture of each mangrove species (Ellison 2005). Study by Chowdhury (2016) concluded that increased water salinity accentuates the abundance of salt-tolerant species with physiological and phenological such as A. marina and decreased abundance of salt-sensitive mangroves such as $R$. mucronata. 
Table 2. List of major components, minor component and associate species of mangrove found in Mimika District, Papua, Indonesia

\begin{tabular}{|c|c|c|c|}
\hline Family & Species & Growth form & Classification $^{\mathrm{a}}$ \\
\hline Arecaceae & Nypa fruticans Wurmb & Rhizomatous palm & $1^{*}$ \\
\hline Avicenniaceae & Avicennia alba $\mathrm{BI}$ & Tree & 1 \\
\hline Avicenniaceae & Avicennia marina (Forssk.) Vierh & Tree & $1^{*}$ \\
\hline Avicenniaceae & Avicennia officialis L. & Tree & $1 *$ \\
\hline Avicenniaceae & Avicennia lanata Ridley & Tree & 1 \\
\hline Combretaceae & Lumnitzera littorea Voigt. & Tree & $1^{*}$ \\
\hline Combretaceae & Lumnitzera racemose Willd & Tree & 1 \\
\hline Combretaceae & Lumnitzera rosea (Gaud.) & Tree & 1 \\
\hline Meliaceae & Xylocarpus granatum Koen. & Tree & $1 *$ \\
\hline Meliaceae & Xylocarpus molusccensis (Lamk) M. Roem. & Tree & $1 *$ \\
\hline Rhizophoraceae & Bruguiera cylindrica (L.) Bl. & Tree & 1 \\
\hline Rhizophoraceae & Bruguiera gymnorrhiza (L.) Lam & Tree & $1 *$ \\
\hline Rhizophoraceae & Bruguiera parviflora (Roxb.) W.\& A. ex Griff. & Tree & $1^{*}$ \\
\hline Rhizophoraceae & Bruguiera sexangula (Lour.) Poir. & Tree & $1 *$ \\
\hline Rhizophoraceae & Ceriops tagal C.B. Rob & Tree & $1 *$ \\
\hline Rhizophoraceae & Rhizophora apiculata Blume & Tree & $1^{*}$ \\
\hline Rhizophoraceae & Rhizophora mucronata Lam & Tree & $1^{*}$ \\
\hline Rhizophoraceae & Ceriops decandra (Griff.) Ding Hou & Tree & 1 \\
\hline Rhizophoraceae & Rhizophora stylosa Griff. & Tree & 1 \\
\hline Sonneratiaceae & Sonneratia alba J.E. Smith. & Tree & $1^{*}$ \\
\hline Sonneratiaceae & Sonneratia caseolaris (L.) Engl. & Tree & 1 \\
\hline Acanthaceae & Acanthus ilicifolius $\mathrm{L}$ & Shrub & 2 \\
\hline Acanthaceae & Acanthus volubilis Wall. & Shrub & 2 \\
\hline Bignoniaceae & Dolichandrone spathacea (1.f.) K. Schum. & Tree & 2 \\
\hline Bombaceae & Camptostemon schultzii Masters. & Shrub/tree & $2 *$ \\
\hline Ebenaceae & Diospyros papuana Valeton ex Bakh. & Tree & 2 \\
\hline Euphorbiaceae & Excoecaria agalocha $\mathrm{L}$. & Tree & $2 *$ \\
\hline Myrsinaceae & Aegiceras corniculatum (L.) Blanco & Shrub/tree & 2 \\
\hline Pteridaceae & Acrosthicum aureum $\mathrm{L}$. & Fern & 2 \\
\hline Rubiaceae & Nauclea papuana Versteeg & Shrub & 2 \\
\hline Rubiaceae & Scyphiphora hydrophyllacea Gaertn. f. & Shrub & 2 \\
\hline Arecaceae & Metroxylon sagu Rottb. & Palm tree & 3 \\
\hline Aizoaceae & Sesuvium portulacastrum (L.) L. & Herb & 3 \\
\hline Amaryllidaceae & Crinum asiaticum $\mathrm{L}$. & Lily & 3 \\
\hline Anacardiaceae & Campnosperma brevipetiolata Volk & Tree & 3 \\
\hline Anacardiaceae & Rhus taitensis Guill & Tree & 3 \\
\hline Apocynaceae & Calotropis gigantea $(\mathrm{L}) \mathrm{R} . \mathrm{Br}$. & Fern & 3 \\
\hline Arecaceae & Gulubia costata (Becc.) Becc. & Palm tree & 3 \\
\hline Arecaceae & Oncosperma tigillarium (Jack.) Ridl. & Palm tree & 3 \\
\hline Asclepiadaceae & Finlaysonia maritima (Blume) Backer ex K. Heyne & Tree & 3 \\
\hline Asteraceae & Pluchea indica (L.) Less. & Shrub & 3 \\
\hline Boraginaceae & Cordia subcordata Lamarck & Tree & 3 \\
\hline Callophylaceae & Callophyllum innophilum $\mathrm{L}$. & Tree & 3 \\
\hline Callophylaceae & Calophyllum soulattri Burm. f. & Tree & 3 \\
\hline Casuarinaceae & Casuarina equisetifolia $\mathrm{L}$. & Tree & 3 \\
\hline Convolvulaceae & Ipomoea pes-caprae (L.) R.Br. & Vine & 3 \\
\hline Convolvulaceae & Ipomoea pes-caprae (L.) Sweet. & Vine & 3 \\
\hline Combretaceae & Terminalia catappa $\mathrm{L}$. & Tree & 3 \\
\hline Fabaceae & Canavalia maritima Thouars. & Herb & 3 \\
\hline Fabaceae & Derris trifoliata Lour & Tree & 3 \\
\hline Fabaceae & Inocarpus fagiver (Parkinson ex Zollinger) Fosberg & Tree & 3 \\
\hline Fabaceae & Intsia bijuga (Colebr.) Kuntze & Tree & 3 \\
\hline Fabaceae & Millettia pinnata (L.) Panigrahi & Tree & 3 \\
\hline Fabaceae & Pongamia pinnata (L.) Pierre & Tree & 3 \\
\hline Fabaceae & Derris trifoliata Lour. & Tree & 3 \\
\hline Goodeniaceae & Scaevola taccada (Gaertn.) Roxb. & Shrub & 3 \\
\hline Lamiaceae & Clerodendrum inerme (L.) Gaertn. & Shrub & 3 \\
\hline Lamiaceae & Vitex ovata Thunb. & Shrub & 3 \\
\hline Lecythidaceae & Barringtonia asiatica (L.) Kurz. & Tree & 3 \\
\hline Malvaceae & Talipariti tiliaceum (L.) Fryxell & Tree & 3 \\
\hline Malvaceae & Thespesia populnea (L.) Soland. ex Correa & Tree & 3 \\
\hline Malvaceae & Heritiera littoralis Aiton & Tree & 3 \\
\hline Moraceae & Ficus microcarpa L. fil & Tree & 3 \\
\hline Myristicaceae & Myristica fatua var Papuana dei Swaiem & Tree & 3 \\
\hline Pandanaceae & Pandanus tectorius Sol. & Shrub/tree & 3 \\
\hline Tetramelaceae & Octomeles sumatrana Miguel & Tree & 3 \\
\hline
\end{tabular}


Table 3. Density, Shannon-Wiener diversity index ( $\left.\mathrm{H}^{\prime}\right)$ and evenness index (J') of the mangrove forest in Mimika District, Papua, Indonesia

\begin{tabular}{llccc}
\hline Location & Location & Tree density (tree ha-1) & $\mathbf{H}^{\mathbf{1}}$ & $\mathbf{J}^{\prime}$ \\
\hline KAM-1 & Kamora Estuary & $722 \pm 96$ & $0.82 \pm 0.16$ & $0.86 \pm 0.10$ \\
KAM-2 & Kamora Estuary & $577 \pm 168$ & $0.88 \pm 0.31$ & $0.77 \pm 0.05$ \\
KAM-3 & Kamora Estuary & $689 \pm 107$ & $0.66 \pm 0.15$ & $0.70 \pm 0.16$ \\
TIP-1 & Tipuka Estuary & $711 \pm 107$ & $0.76 \pm 0.52$ & $0.49 \pm 0.24$ \\
TIP-2 & Tipuka Estuary & $878 \pm 204$ & $1.07 \pm 0.36$ & $0.81 \pm 0.19$ \\
AJK-1 & Ajkwa Estuary & $767 \pm 88$ & $1.19 \pm 0.14$ & $0.92 \pm 0.06$ \\
AJK-2 & Ajkwa Estuary & $711 \pm 126$ & $0.94 \pm 0.45$ & $0.61 \pm 0.42$ \\
AJK-3 & Ajkwa Estuary & $1345 \pm 414$ & $1.12 \pm 0.47$ & $0.80 \pm 0.05$ \\
MIN-1 & Minajerwi Estuary & $756 \pm 301$ & $0.62 \pm 0.09$ & $0.73 \pm 0.25$ \\
\hline
\end{tabular}

The evenness index (J') ranged from 0.61-0.92, which is classified as high. The highest evenness index (0.92) was recorded at AJK-1 in the Ajkwa Estuary, whereas the lowest (0.49) was found at TIP-1 in the Tipuka Estuary.

The canopy heights of the mangrove trees are shown in Figure 3. The tallest mangroves were found at AJK-1 at 0 $\mathrm{m}(43 \mathrm{~m})$ and the shortest at AJK-2 at $0 \mathrm{~m}(10 \mathrm{~m})$. AJK-1 also had the highest average canopy height of $39 \mathrm{~m}$. Nevertheless, there was no consistent pattern in height difference at 0,250 , and $500 \mathrm{~m}$. In five of the nine locations, the mangroves nearest the shoreline were the shortest, probably because they were generally the youngest trees. Study from Lugo \& Medina (2014) found that the tree height decreases following environmental gradients from low to high salinity, low to high wind speed, high to low air temperature, high to low nutrient availability, and high to low rainfall.

Figures 4 and 5 provide the plots for the densities and basal areas of the most dominant species in the study area. The highest density was recorded for $R$. apiculata with a median of 333 trees ha ${ }^{-1}$ followed by $A$. marina, $B$. gymnorrhiza, and C. schultzii. In contrast, B. parviflora, $S$. alba, and $X$. granatum were found to be the least dense. For the basal area, $R$. apiculata and B. gymnorrhiza were found to have among the highest with median basal areas of 7,853 $\mathrm{cm}^{2} \mathrm{ha}^{-1}$ and 5,201 $\mathrm{cm}^{2} \mathrm{ha}^{-1}$ respectively. Trees with a lower basal area were C. schultzii, B. parviflora, S. alba, A. marina, and $X$. granatum.

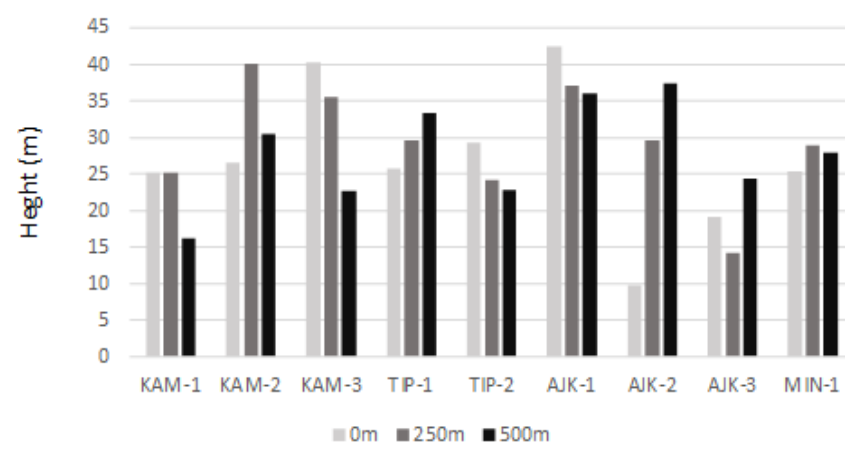

Figure 3. Average canopy height of the mangrove trees in Mimika District, Papua, Indonesia Vegetation composition and structure

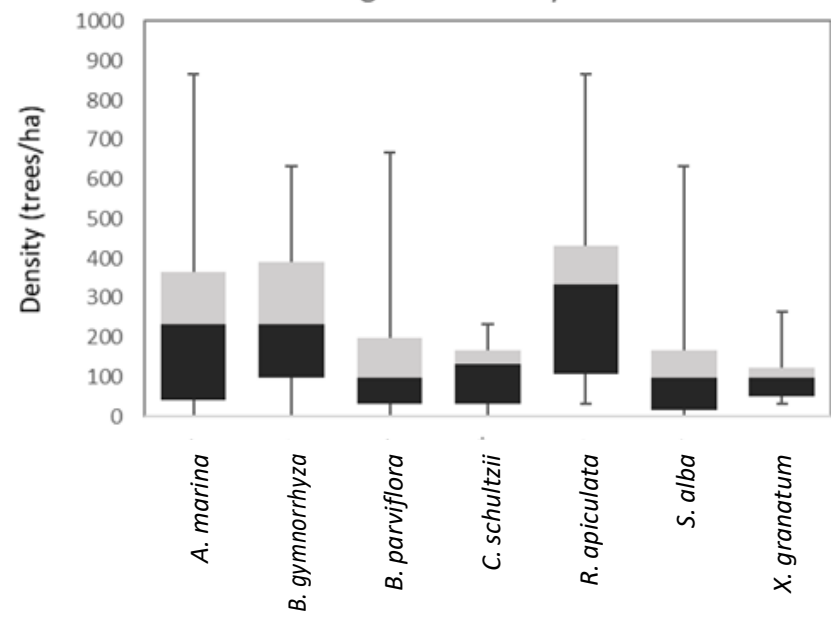

Figure 4. Mangrove density of dominance species of the mangrove forest in Mimika District, Papua, Indonesia

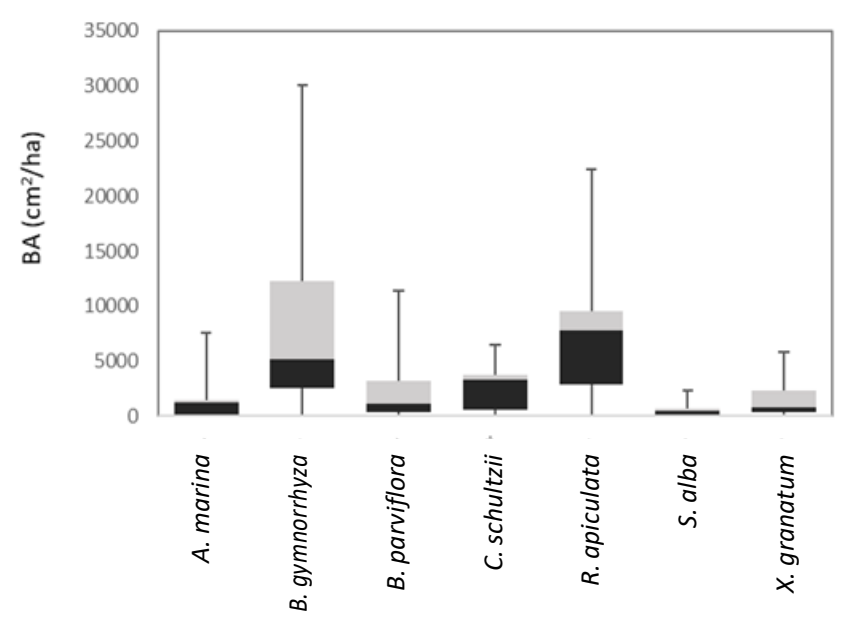

Figure 5. Basal area of dominant species of mangrove forest in the Mimika Region, Mimika District, Papua, Indonesia

\section{Species importance value}

Based on the Species Importance Values (SIV), $R$. apiculata, B. gymnorrhiza, and A. marina are the most dominant species. These SIV are $121 \pm 58$ for A. marina, $119 \pm 63$ for $R$. apiculata, and $115 \pm 61$ for B. gymnorrhiza. Both $R$. apiculata and B. gymnorrhiza are found at all locations. The SIV of each sampling location is illustrated 
in Figure 5. Both R. apiculata and B. gymnorrhiza are dominant in all locations excluding AJK-3, which is dominated by $A$. marina and S. alba.

The dominant of few mangrove species across all sampling locations can result in favorable conditions to those dominant species. A study in Srilanka by Cooray (2021) showed that the main drivers of the variability in mangrove vegetation structure and composition were soil salinity and nutrients, which is consistent study by Barick et al (2014) where salinity is the main factor influencing mangrove community zones. Since the mangrove forest community extends about $20 \mathrm{~km}$ inland from the coastline, this fast mangrove forest may provide more homogenous environmental conditions which resulting in dominance for only few mangrove species. The high and dense tree canopy may be resulting less light penetration to the mangrove floor which may limit mangrove colonization by other species (Lettow 2014).

\section{Mangrove zonation}

Mangrove zonation in Mimika District from swamp forest down to the coastline, a $20 \mathrm{~km}$ stretch of land, is shown in Figure 7. Mangrove areas can be classified into four tidal zones: low, medium-low, medium-high, and high. This classification is based on the elevation data obtained by LIDAR in which the low tidal zone is $<0.5 \mathrm{~m}$; the medium -ow tidal zone is $0.5-1.5 \mathrm{~m}$; the medium-high tidal zone is $1.5-2 \mathrm{~m}$; and the high tidal zone is $>2 \mathrm{~m}$. Using the 2019 Tide Table provided by www.pushidrosal.id, the estimated inundation of the low tidal zone is $>4,800 \mathrm{hr} \mathrm{yr}^{-1}$ or $>55 \%$ of the year $(8,760$

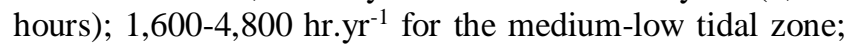
$600-1,600 \mathrm{hr}_{\mathrm{yr}} \mathrm{y}^{-1}$ for the medium-high tidal zone; and <

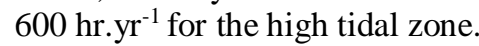

Each tidal zone is dominated by one or two species. The low tidal zone, particularly the newly colonized area, is dominated by A. marina and S. alba. R. mucronata, which are commonly found along riverbanks. A good representative example of this zone is AJK-3 in the seaward margin of the Ajkwa Estuary (see Figure 7) where $R$. apiculata followed by $B$. gymnorrhiza are the most dominant species. B. parviflora is widely distributed and can be found in three zones, (i.e., the medium-low tidal, medium-high tidal, and high tidal zones) was. The high tidal zone features low salinity and marks the point of transition of the mangrove forest into swamp forest. This zone is dominated by $N$. fruticans

\section{Discussion}

A total of 66 species were found in this study comprising of 20 species of major mangrove components, 10 species of minor components and 36 species of mangrove associates. Other studies conducted in Papua have similarly found these same 20 major mangrove components species. Most mangrove associates are typically found in the landward margin of the mangal and often in non-mangal habitats such as rainforest, salt marsh, or lowland freshwater swamps. Previous research has recorded 11 species of mangrove trees at 2 sites in the Tipuka Estuary, Mimika (Kusmana et al. 1998, unpublished report; Ellison 2005). A study conducted in Bintuni Bay, West Papua recorded 28 true mangrove species representing 11 families (Yudha et al. 2021), while Lekitoo and Tambing (2018) only recorded 13 mangrove plant species belonging to 6 families in the same area.

The mangrove forest communities found in Mimika District are similar to those studied by Robertson et al. (1991) in Papua New Guinea who record 29 mangrove plant species comprising 3 major forest types in the delta, namely Rhizophora-Bruguiera, Nypa, and AvicenniaSonneratia. According to Ellison (2005), the mangrove flora of southern Papua New Guinea consists of 32 mangrove species and 1 hybrid belonged to 15 genera and 13 families.

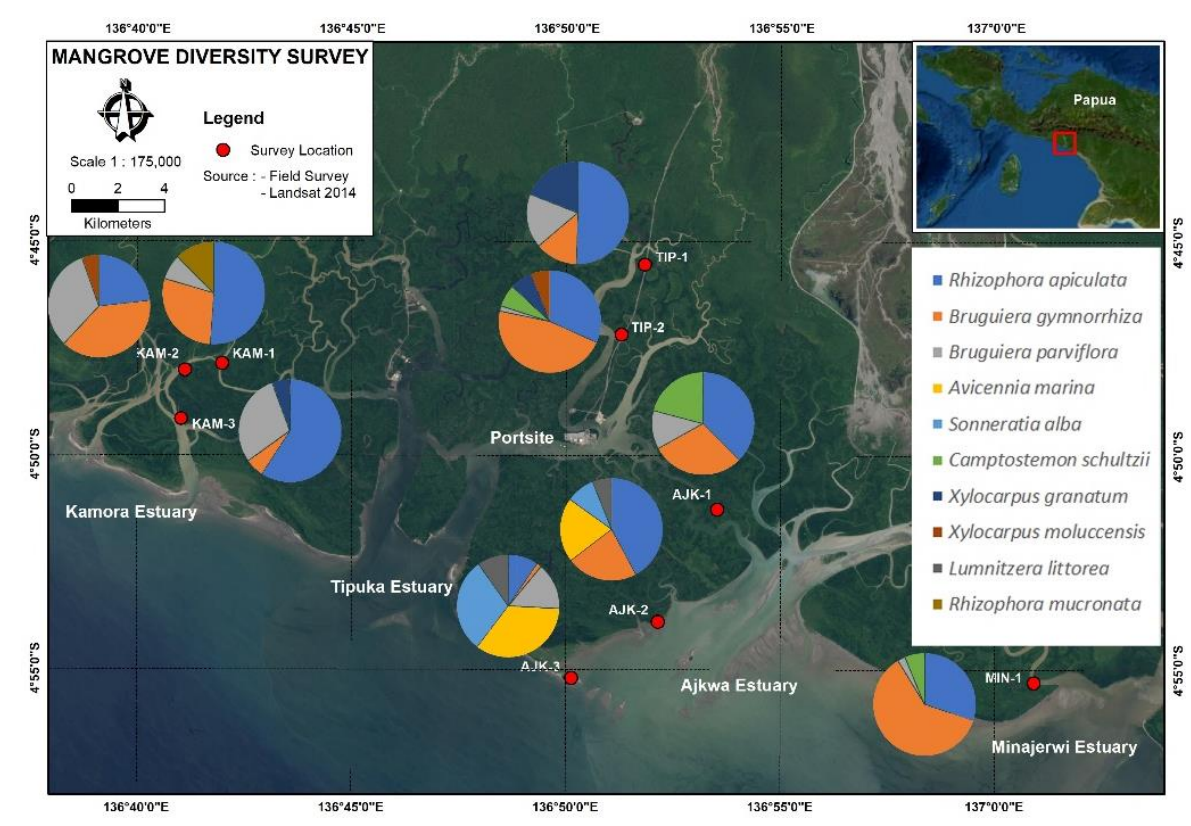

Figure 5. SIV of the mangrove forest in Mimika District, Papua, Indonesia 


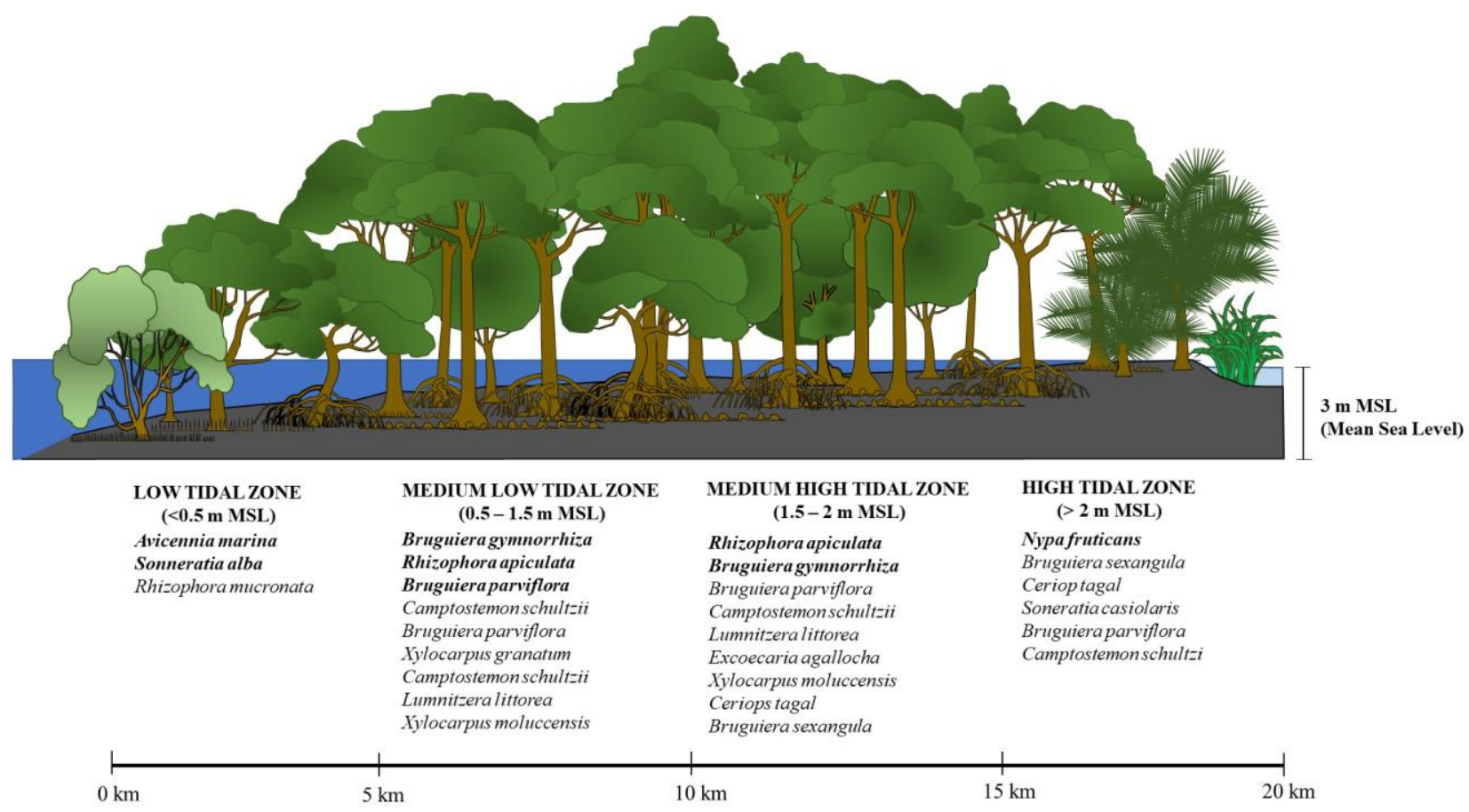

Figure 7. Mangrove zonation in Mimika District, Papua, Indonesia from the coastline until $20 \mathrm{~km}$ inland with dominant species (bold fond is the dominant species)

The mangrove density of Mimika District ranges from 577-1,345 trees ha ${ }^{-1}$, a bit higher than that found in Bintuni, which ranges from 372-544 trees $\mathrm{ha}^{-1}$ (Pribadi 1998). Other studies in Mimika report densities of 319-569 trees ha ${ }^{-1}$ (Kusmana et al. 1998). Mangrove density in the study area was much lower than in other mangrove areas in Indonesia, such as Segara Anakan, and Central Java (8,000 trees ha-1, Hinrich et al. 2009), Lamongan and East Java (2553 trees ha $^{-1}$; Arif et al. 2019), Aceh Besar (1,200-3,200 trees ha ${ }^{-1}$, Permatasari et al. 2018), and West Sumatra (900-1,450 trees $\mathrm{ha}^{-1}$; Rizal and Anna 2020). However, the density values recorded here are comparable to those found in West Kalimantan, which range from 623-740 trees ha $^{-1}$ (Nugroho et al. 2019). The lower mangrove density in Mimika reflects a more mature mangrove ecosystem and an absence of disturbance, which has allowed the mangrove trees to grow to their maximum height (see Figure 3). The study finds a mangrove tree height range of 9-42.5 m. This is consistent with previous studies, which report various average mangrove tree heights of 2.7-45 m (Brunskill 2004; Ellison 2005; Aslan et al. 2016). Taller mangrove trees, particularly $R$. apiculata and B. gymnorrhiza, were found in the medium tidal zone. The maximum height recorded for B. gymnorrhiza was $58 \mathrm{~m}$ and $59.3 \mathrm{~m}$ for $R$. apiculata. The highest tree recorded in this study $(59.4 \mathrm{~m})$ was B. parviflora found at KAM-2 in the Kamora Estuary. The typical diameter of the trees ranged from $30-50 \mathrm{~cm}$ with a maximum of $69 \mathrm{~cm}$ recorded for $R$. apiculata. Shorter mangroves (A. marina and S. alba) were mostly colonized in the newly-developed mud flats or at the riverbanks. Here, the maximum height of A. marina was 16 $\mathrm{m}$, whereas $S$. alba was $14 \mathrm{~m}$. Shorter mangrove species were also found at the riverbank, which was dominated by

\section{R. mucronata.}

The assumed maturity of the mangrove forest in Mimika is supported by the basal area measurements of 24$90 \mathrm{~m}^{2} \mathrm{ha}^{-1}$. These basal area measurements are within the range of previous research conducted in Bintuni, Papua, where basal areas have been found to range from 28.3-36.9 $\mathrm{m}^{2} \mathrm{ha}^{-1}$ (Pribadi 1998), and an existing study of Mimika (22.9-33.6 $\mathrm{m}^{2} \mathrm{ha}^{-1}$; Kusmana et al. 1998). They are also consistent with data from Galley Reach, Papua New Guinea (30 $\mathrm{m}^{2} \mathrm{ha}^{-1}$; Paijmans and Rollet 1977). Basal area measurements in Papua are higher than those found in the mangrove forests of some other regions in Indonesia, such as in Segara Anakan and Java $\left(19.4 \mathrm{~m}^{2} \mathrm{ha}^{-1}\right.$; Hinrich et al. 2009) and the Kayan-Sembakung Delta in North Kalimantan (44.5 m $\mathrm{ha}^{-1}$; Seftianingrum et al. 2020). The basal area measurements recorded in this study are also higher than in the mangrove forests of the Andaman Islands, India (30.8-59.6 $\mathrm{m}^{2}$ ha $^{-1}$; Kiruba-Sankar 2018) and the Sundarban Delta, India (0.4-13.4 $\mathrm{m}^{2} \mathrm{ha}^{-1}$; Sreelekshmi 2020).

The high basal area is evidence that mangroves in Mimika are a pristine mangrove forest. Compared with another pristine forests such as pristine forest in Sarawak, Malaysia (Shah et al. 2016), mangrove forests in Mimika had higher diameters and three heights. The very minimum disturbance from human activity and less environmental disaster resulting mangrove species in this area can grow to maximum height.

The vast and healthy mangrove forest in Mimika, of a total area of 186,291 ha (Aslan et al. 2018), may have been enhanced by sedimentation. Sediment is the result of rainfall-driven erosion in the mountains, which creates large river catchments (Brunskill et al. 2004). The 
mountains of Papua, with Puncak Java the highest elevation in the region at $4,884 \mathrm{~m}$ above sea level, have resulted from the rapid convergence of the Australian and Pacific plates (Baldwin et al. 2012). The combination of high elevation and high rainfall has resulted in high erosion, creating sediment deposition in coastal areas. These newly created soft-bottom sediments deposited in the estuary mouth have been rapidly colonized by a vast mangrove forest. Sedimentation is known to be a contributing factor of mangrove diversity and density (MacKenzie et al. 2016).

The maturity of the mangrove forest in Mimika might affect the dominance of some mangrove species and be responsible for the low Shannon-Wiener diversity index of 0.62-1.19. Mangrove diversity has been retarded because of the high level of canopy cover, which reduces light penetration to the mangrove floor, limiting colonization by other mangrove species. Several forest studies have concluded that the forest canopy affects understory light levels, impacting plant growth and survival, as well as diversity due to the effects of light competition between plants (Lettow 2014; Berrill et al. 2017). Among the locations studied here, the highest diversity index was found at AJK-3 in the Ajkwa Estuary (1.79). This location has the lowest average canopy cover compared with other locations because it is nearest the seaward zone where new colonization takes place. The average canopy height of this location is $19 \mathrm{~m}$ compared with the average height of all locations of $28 \mathrm{~m}$. This data supports the assumption that a lower canopy height allows more light penetration, which, in turn, increases plant growth and natural succession. The high density in this seaward location (1.794 trees ha ${ }^{-1}$ ) shows that new colonization occurs alongside the presence of some pioneer species such as A. marina and $S$. alba. Fajri et al. (2012) also identify $S$. alba as the most dominant species colonizing a new island in the Ajkwa Estuary.

The most dominant species at all locations are $R$. apiculata and B. gymnorrhiza, as seen in the Species Importance Values (SIV). Kusmana et al. (1998) also find both these dominant species in the same area. Kusmana et al. (1998) also record two community types of mangrove: the B. Gymnorrhiz--C. schultzii-R. apiculata community and the B. cylindrica-R. apiculata community, with $R$. apiculata having the highest density.

This study classifies the mangrove zones in Mimika based on seawater inundation as low, medium-low, medium-high, and high tidal zones with a diurnal tidal regime of $3.4 \mathrm{~m}$. The only classification of mangrove areas in Mimika was previously made by Ellison (2005), who distinguishes five community distributions of mangrove, i.e., the seaward pioneer community at the lowest elevations, which is dominated by Avicennia and Sonneratia, the $R$. stylosa-B. gymnorrhiza dominated area at the south of the estuaries and outer bends of the rivers, the $B$. dominated area at slightly higher elevations, the $N$. fruticans area, and the mixed mangrove area on the margins of freshwater areas.

This study shows that in the low tidal zone, A. marina and $S$. alba are the dominant species. This is consistent with many studies that have concluded that $A$. marina and $S$. alba have an adaptive mechanism that enables them to withstand higher salinity levels (Hasegawa et al. 2014; Almahasheer et al. 2016). Moreover, R. apiculata and B. gymnorrhiza are found to be dominant in medium-low and medium-high tidal zones. Both species appear to have a high tolerance of salinity. Salinity is the main factor influencing mangrove community zones and each mangrove species has different salinity tolerance (Barik et al. 2014). In this study, the species found to be the most adaptable to different inundation and salinity levels is $B$. parviflora. This species can be found in three zones, i.e., medium-low, medium-high, and high tidal zones. Using the classification regime proposed by van Loon et al. (2007), Bruguiera is found in normal high tide and spring high tide areas with a monthly flooding frequency of 2-45 times. The high tidal zones in the study area of this research are areas where the mangrove forest transitions to freshwater swamp or rainforest. Other Bruguiera genera, such as $B$. sexangular, are also found but at low densities as this zone is dominated by $N$. fruticans.

The study shows that the mangrove ecosystem in this part of Mimika is very rich in mangrove tree diversity. Due to the vast mangrove area in Mimika District, more detailed research is needed to further explore this magnificent mangrove forest in Papua, which is likely to be the most pristine and diverse mangrove forest in the world. The results of such research will be very valuable for sustainable mangrove resource management in Papua, Indonesia, which has mangrove forests covering a total area of almost 1.5 million hectares.

\section{ACKNOWLEDGEMENTS}

We would like to thank PT Freeport Indonesia for their support in conducting this study and the Mangrove Team in the Department of Marine Science, Faculty of Fishery and Marine Science, Universitas Diponegoro, for their involvement in collecting data in the field. Thank you also to Dr. Jurgenne Primavera and Dr. Tengku Zia Ulqodry for reviewing this manuscript and providing valuable inputs. The authors declare no competing interests.

\section{REFERENCES}

Alavaisha E, Mangora MM. 2016. Carbon stocks in the small estuarine mangroves of Geza and Mtimbwani, Tanga, Tanzania. Intl J For Res 2016: 2068283. 11 DOI: 10.1155/2016/2068283.

Almahasheer H, Duarte C, Irigoien X. 2016. Phenology and growth dynamics of Avicennia marina in the Central Red Sea. Sci Rep 6: 37785. DOI:10.1038/srep37785.

Asadi MA, Rahardani AM, Semedi B, Soegianto A. 2019. Carbon storage of mangrove ecosystems in Pasuruan and Probolinggo District, East Java, Indonesia. Ecol Environ Conserv 2019: S162-S167. DOI:10.13140/RG.2.2.12317.67045

Aslan A, Rahman AF, Robesond SM. 2018. Investigating the use of Alos Prism data in detecting mangrove succession through canopy height estimation. Ecol Indicat 87: 136-143. DOI:10.1016/j.ecolind.2017.12.008.

Baldwin SL, Fitzgerald PG, Webb LE. 2012. Tectonics of the New Guinea Region. Ann Rev Earth Planetary Sci 40: 495-520. DOI: 10.1146/annurev-earth-040809-152540. 
Barik J, Mukhopadhyay A, Ghosh T, Mukhopadhyay SK, Chowdhury SM, Hazra S. 2014. Mangrove species distribution and water salinity: an indicator species approach to Sundarban. J Coast Conserv. DOI: 10.1007/s11852-017-0584-7.

Berrill JP, Dagley CM, Coppeto SA, Gross SE. 2017. Curtailing succession: Removing conifers enhances understory light and growth of young aspen in mixed stands around Lake Tahoe, California and Nevada, USA. For Ecol Manag 400: 511-522. DOI: 10.1016/j.foreco.2017.06.001.

Brunskill GJ, Zagorskis I, Pfitznera J, Ellison J. 2004. Sediment and trace element depositional history from the Ajkwa River estuarine mangroves of Irian Jaya (West Papua), Indonesia. Continent Shelf Res 24: 2535-2551. DOI: 10.1016/j.csr.2004.07.024.

Chowdhury, Q., P. Sanyal, S.K. Maiti. 2016. Dynamics of mangrove diversity influenced by climate change and consequent accelerated sea level rise at Indian Sundarbans. Intl J Global Warm 9: 4. DOI: 10.1504/IJGW.2016.076333.

Ellison JC. 2005. Holocene palynology and sea-level change in two estuaries in Southern Irian Jaya. Paleogeogr Paleoclimatol Paleoecol 220(3-4):291-309. DOI: 10.1016/j.palaeo.2005.01.008

Cintron G, Novelli YS. 1984. Methods for studying mangrove structure In: Snedaker SC and Snedaker JG (eds.) The Mangrove Ecosystem: Research Methods. UNESCO, Paris.

Fajri, Subardjo P, Pribadi R. 2012. Studies on Mangrove Vegetation Change Area by Using Landsat TM and Landsat 7 ETM + During The Years 1998 to 2010 in Mimika District Coastal, Papua. J Mar Res 1 (1):146-145. DOI: $10.14710 /$ jmr.v1i1.2002

Ganivet E, Bloomberg M. 2019. Towards rapid assessments of tree species diversity and structure in fragmented tropical forests: A review of perspectives offered by remotely-sensed and field-based data, For Ecol Manag 432: 40-53. DOI: 10.1016/j.foreco.2018.09.003.

Giri C, Ochieng E, Tieszen LL, Zhu Z, Singh A, Loveland T, Masek J, Duke N. 2011. Status and distribution of mangrove forests of the world using earth observation satellite data. Global Ecol Biogeogr 20 (1): 154-159. DOI: $10.1111 / \mathrm{j} .1466-8238.2010 .00584 . \mathrm{x}$

Hanum IF, Latiff A, Hakeem KR, Ozturk M. 2014. Mangrove Ecosystems of Asia: Status, Challenges and Management Strategies, Springer.

Hasegawa A, Oyanagi T, Minagawa R. et al. 2014. An inverse relationship between allelopathic activity and salt tolerance in suspension cultures of three mangrove species, Sonneratia alba, $S$. caseolaris and $S$. ovata: development of a bioassay method for allelopathy, the protoplast co-culture method. J Plant Res 127: 755761. DOI:10.1007/s10265-014-0651-1

Hinrichs S, Nordhaus I, Geist SJ. 2009. Status, diversity and distribution patterns of mangrove vegetation in the Segara Anakan Lagoon, Java, Indonesia. Reg Environ Ch 9: 275-289. DOI: $10.1017 / \mathrm{S} 0376892902000231$.

Hogarth PJ. 2015. The biology of mangroves and seagrasses. Oxford University Press, UK.

Ilman M, Wibisono ITC, Suryadiputra INN. 2011. State of the Art Information on Mangrove Ecosystems in Indonesia. Wetland International-Indonesia Programme, Bogor. DOI: 10.13140/RG.2.1.3967.9120

Johnstone IM, Frodin DG. 1982. Mangroves of the Papuan Subregion. In Gressitt JL (eds.). Biogeography and Ecology of New Guinea. Monographiae Biologicae, Vol. 42. Springer, Dordrecht. DOI:10.1007/978-94-009-8632-9_22

Kiruba-Sankar R, Krishnan P, Dam Roy S, et al. 2018. Structural complexity and tree species composition of mangrove forests of the Andaman Islands, India. J Coast Conserv 22: 217-234. DOI: 10.1007/s11852-017-0588-3.

Lekitoo K, Tambing Y. 2018. The Vegetation Structure of Mangrove at Coastal Area of Sumuri, Bintuni Bay, West Papua. Vogelkop Jurnal Biologi 1 (1): 76-81. DOI: 10.30862/vogelkopjbio.v1i2.47

Lettow MC, Brudvig LA, Bahlai CA, Landis DA. 2014. Oak savanna management strategies and their differential effects on vegetative structure, understory light, and flowering forbs. For Ecol Manag 329: 89-98. DOI:10.1016/j.foreco.2014.06.019.

Lugo AE, Medina E. 2014. Mangrove forests. In: Encyclopedia of Natural Resources - Land. Vol. 1. Taylor and Francis, New York. DOI: 10.1081/E-ENRL-120047500.

Nugroho TS, Fahrudin A, Yulianda F, Bengen DG. 2019. Structure and composition of riverine and fringe mangroves at Muara Kubu protected areas, West Kalimantan, Indonesia. Aquacult Aquarium Conserv Legisl Cluj-Napoca 12 (1): 378-393.
MacKenzie RA, Foulk PB, Klump JV, et al. 2016. Sedimentation and belowground carbon accumulation rates in mangrove forests that differ in diversity and land use: a tale of two mangroves. Wetlands Ecol Manag 24: 245-261 (2016). DOI:10.1007/s11273-016-9481-3.

Mueller-Dumbois D, Ellenberg H. 1974. Aims and Methods of Vegetation Ecology. Wiley and Sons, New York.

Krebb CJ. 1989. Ecological Methodology. Harpercollins College Div., New York.

Kusmana C, Puradyatmika P, Husin YA, Sea G, Martindale D. 1998. Mangrove Litter-Fall Studies at the PT Freeport Indonesia Project Area. Report by PT Hatfindo Prima to PT Freeport Indonesia, Jakarta.

Kusmana C. 2015. Integrated sustainable mangrove management. J Resour Environ Manag 5 (1): 1-6. DOI: 10.29244/jps1.5.1.1

Paijmans K, Rollet B. 1977. The mangroves of Galley Reach, Papua New Guinea. Forest Ecol Manag 1 (1976-1970): 119-140. DOI: 10.1016/0378-1127(76)90016-5

Pielou EC. 1975. Ecological Diversity. Wiley, New York.

Permatasari, Dewiyanti, Purnawan S, Yuni SM, Irham M, Setiawan I. 2018. The correlation between mangrove density and suspended sediment transport in Lamreh Estuary, Mesjid Raya Subdistrict, Aceh Besar, Indonesia. The International Conference on Fisheries, Aquatic, and Environmental Sciences (ICFAES 2018), Banda Aceh, Indonesia. DOI: $10.1088 / 1755-1315 / 216 / 1 / 012004$.

Pribadi R. 1998. The ecology of mangrove vegetation in Bintuni Bay, Irian Jaya, Indonesia. [Dissertation]. University of Stirling, UK.

Rizal A, Anna Z. 2020. The effect on mangrove density with sediment transport rate in Sikakap Coastal Area of Mentawai Island District, West Sumatra Province, Indonesia. World Sci News 146: 202-214.

Rizal A, Sahidin A, Herawati H. 2018. Economic value estimation of mangrove ecosystems in Indonesia. Biodiversity Intl J 2 (3):00051. DOI: $10.15406 / \mathrm{bij} .2018 .02 .00051$.

Robertson AI, Daniel PA, Dixon P. 1991. Mangrove forest structure and productivity in the Fly River estuary, Papua New Guinea. Mar Biol 111: 147-155. DOI: 10.1007/BF01986356

Seftianingrum R, Suwasono RA, Sulistioadi YB, Suhardiman A, Diana R. 2020. Floral composition of the Kayan-Sembakung Delta in North Kalimantan (Indonesia) in different disturbance regimes. J Coast Res 36 (4): 741-751. DOI: 10.2112/JCOASTRES-D-18-00145.1

Shah K, Kamal AHM, Rosli Z, Hakeem KR, Hoque MM. 2016. Composition and diversity of plants in Sibuti mangrove forest, Sarawak, Malaysia. For Sci Technol 12 (2): 70-76, DOI: 10.1080/21580103.2015.1057619.

Shannon CE, Wiener W. 1963. The Mathematical Theory of Communication. University of Illinois Press, Urbana, IL.

Shearman PL, Bryan JE, Ash J, Mackey B, Lokes B. 2009 Forest conversion and degradation in Papua New Guinea 1972-2002. Biotropica 41 (3): 379-390. DOI:10.1111/j.1744-7429.2009.00495.x.

Shearman PL. 2010. Recent Change in the Extent of Mangroves in the Northern Gulf of Papua, Papua New Guinea. Ambio 39 (2): 181-189. DOI: $10.1007 / \mathrm{s} 13280-010-0025-4$.

Sreelekshmi S, Nandan SB, Kaimal SV, Radhakrishnan CK, Suresh VR. 2020. Mangrove species diversity, stand structure and zonation pattern in relation to environmental factors - A case study at Sundarban delta, east coast of India. Reg Stud Mar Sci 35: 101111. DOI: 10.1016/j.rsma.2020.101111.

Setyadi G, Kastoro WW, Rahayu DL, Haris A, Dwiono SAP, Kailola P. 2009. Biota aquatic of Mimika Waters, Papua. PT Freeport Indonesia and Research Center for Oceanography-Indonesian Institute of Sciences, Jakarta

Taberima S, Nugroho YD, Murdiyarso D. 2014. The Distribution of Carbon Stock in Selected Mangrove Ecosystem of Wetlands Papua: Bintuni, Teminabuan, and Timika Eastern Indonesia. International Conference on Chemical, Environment \& Biological Sciences (CEBS-2014), 2014 Kuala Lumpur, Malaysia. DOI: 10.15242/IICBE.C914072.

Tusinski A, Verhagen HJ. 2014. The use of mangrove in coastal protection. Coastal Engineering and Proceeding 1 (34): 45. DOI: 10.1504/IJGW.2018.094312.

Yudha RP, Sugito YS, Sillanpää M, Nurvianto S. 2021. Impact of logging on the biodiversity and composition of flora and fauna in the mangrove forests of Bintuni Bay, West Papua, Indonesia. For Ecol Manag 488: 119038. DOI: 10.1016/j.foreco.2021.119038.

Williams MS, Bechtold WA, LaBau VJ. 1994. Five instruments for measuring tree height: an evaluation. Southern J Appl For 18 (2): 7682. DOI: $10.1093 / \mathrm{sjaf} / 18.2 .76$. 